\title{
DISTRIBUTED GENERATION: DEFINITION, BENEFITS AND ISSUES
}

\author{
G. Pepermans, J. Driesen, D. Haeseldonckx, \\ R. Belmans and W. D'haeseleer
}

Revised version - 29 September 2003

\begin{abstract}
This paper starts from the observation that there is a renewed interest in small-scale electricity generation. The authors start with a survey of existing small-scale generation technologies and then move on with a discussion of the major benefits and issues of small-scale electricity generation. Different technologies are evaluated in terms of their possible contribution to the listed benefits and issues. Small-scale generation is also commonly called distributed generation, embedded generation or decentralised generation. In a final section, an attempt is made to define the latter concepts more precisely. It appears that there is no consensus on a precise definition as the concept encompasses many technologies and applications.
\end{abstract}

Keywords: Distributed generation, embedded generation, electricity

\section{Corresponding Addresses: Guido Pepermans}

K.U.Leuven Energy Institute

Naamsestraat 69

B-3000 Leuven

Belgium

e-mail: guido.pepermans@econ.kuleuven.ac.be

Johan Driesen

K.U.Leuven Energy Institute

Kasteelpark Arenberg 10

B-3001 Leuven

Belgium

e-mail: johan.driesen@esat.kuleuven.ac.be

Dries Haeseldonckx

K.U.Leuven Energy Institute

Celestijnenlaan 300A

B-3001 Leuven

Belgium

e-mail: dries.haeseldonckx@mech.kuleuven.ac.be 


\section{Distributed Generation: Definition, Benefits and Issues ${ }^{i}$}

Distributed generation, for the moment loosely defined as small-scale electricity generation, is a fairly new concept in the economics literature about electricity markets, but the idea behind it is not new at all. In the early days of electricity generation, distributed generation was the rule, not the exception. The first power plants only supplied electricity to customers in the close neighbourhood of the generation plant. The first grids were DC based, and therefore, the supply voltage was limited, as was the distance that could be used between generator and consumer. Balancing demand and supply was partially done using local storage, i.e. batteries, which could be directly coupled to the DC grid. Along with small-scale generation, local storage is also returning to the scene.

Later, technological evolutions, such as the emergence of AC grids, allowed for electricity to be transported over longer distances, and economies of scale in electricity generation lead to an increase in the power output of the generation units. All this resulted in increased convenience and lower per unit costs. Massive electricity systems were constructed, consisting of huge transmission and distribution grids and large generation plants. Balancing demand and supply was done by the averaging effect of the combination of large amounts of instantaneously varying loads. Security of supply was increased as the failure of one power plant was compensated by the other power plants in the interconnected system. In fact this interconnected high voltage system made the economy of scale in generation possible.

In the last decade, technological innovations and a changing economic and regulatory environment have resulted in a renewed interest for distributed generation. This is confirmed by the IEA (2002), who lists five major factors that contribute to this evolution, i.e. developments in distributed generation technologies, constraints on the construction of new transmission lines, increased customer demand for highly reliable electricity, the electricity market liberalisation and concerns about climate change.

This paper presents a rather general discussion of distributed generation. The first section deals with the technologies that allow small-scale generation of electricity. The main characteristics of each technology are summarised in a table. Section 2 then discusses the major potential benefits that are linked to the use of distributed generation. Section 3 focuses on the major issues that are raised in the distributed generation literature. In both sections, we present a table that links the technologies discussed in section 1 to the different benefits and issues discussed. This will illustrate that many of the benefits and issues depend on the distributed generation technology used. Section 4 then tries to define distributed generation. This appears to be difficult, as the answer depends on the problem being looked at. Finally, section 5 concludes.

\section{DISTRIBUTED GENERATION TECHNOLOGIES}

This section presents a table listing the different technologies that can be used for small-scale electricity generation. The different technologies are not discussed in great detaili". For a 
discussion of the advantages and disadvantages of distributed generation, we refer to the sections 2 and 3 . 


\begin{tabular}{|c|c|c|c|c|c|c|}
\hline & General information & Application range & $\begin{array}{c}\text { Electric conversion } \\
\text { efficiency }\end{array}$ & Application & Fuel & Comments \\
\hline $\begin{array}{l}\text { Reciprocating } \\
\text { Engines }\end{array}$ & & $\begin{array}{l}\text { - Diesel: } 20 \mathrm{~kW}_{\mathrm{e}}- \\
10+\mathrm{MW} \mathrm{W}_{\mathrm{e}}(\mathrm{IEA}) \\
\text { - Gas: } 5 \mathrm{~kW}_{\mathrm{e}}-5+\mathrm{MW}_{\mathrm{e}} \\
\text { (IEA) } \\
\text { - By far most common } \\
\text { technology below } 1 \mathrm{MW}_{\mathrm{e}}\end{array}$ & $\begin{array}{l}\text { - Diesel: } 36 \%-43 \% \text { (IEA) } \\
\text { - Gas: } 28 \%-42 \% \text { (IEA) }\end{array}$ & $\begin{array}{l}\text { - Emergency or standby } \\
\text { services } \\
\text { - } \mathrm{CHP}\end{array}$ & $\begin{array}{l}\text { - Diesel, also heavy fuel } \\
\text { oil and bio-diesel } \\
\text { - Gas, mainly natural gas, } \\
\text { biogas and landfill gas } \\
\text { can also be used }\end{array}$ & \\
\hline Gas turbines & & • 1 - $20 \mathrm{MW}_{\mathrm{e}}(\mathrm{IEA})$ & - $21 \%-40 \%$ (IEA) & $\begin{array}{l}\text { - } \text { CHP } \\
\text { - Peak power supply } \\
\text { units }\end{array}$ & - Gas, kerosene & \\
\hline Micro turbines & & $\begin{aligned}- & 30 \mathrm{~kW}_{\mathrm{e}}-200 \mathrm{~kW}_{\mathrm{e}}(\mathrm{IEA}) \\
& 35 \mathrm{~kW}_{\mathrm{e}}-1 \mathrm{MW}_{\mathrm{e}}(\mathrm{A}) \\
\cdot & \text { Small-scale applications } \\
& \text { up to }<1 \mathrm{~kW}_{\mathrm{e}}\end{aligned}$ & - $25 \%-30 \%$ (IEA) & $\begin{array}{l}\text { Power generation, } \\
\text { possible with CHP } \\
\text { added }\end{array}$ & $\begin{array}{l}\text { Generally uses natural } \\
\text { gas, but flare, landfill } \\
\text { and biogas can also be } \\
\text { used }\end{array}$ & \\
\hline Fuel cells & $\begin{array}{l}\text { - Molten carbonate: } \\
\text { MCFC } \\
\text { - Proton-exchange } \\
\text { membrane: PEMFC } \\
\text { - Solid oxide: SOFC } \\
\text { - Phosphoric acid: PAFC } \\
\text { - Direct Methanol : DMFC } \\
\text { Only PAFC is currently } \\
\text { commercially available }\end{array}$ & $\begin{array}{l}\text { - } 50 \mathrm{~kW}_{\mathrm{e}}-1+\mathrm{MW}_{\mathrm{e}}(\mathrm{IEA}) \\
\text { - PAFC: } 200 \mathrm{~kW}_{\mathrm{e}}-2 \mathrm{MW} \mathrm{W}_{\mathrm{e}} \\
\text { - } \mathrm{MCFC}: 250 \mathrm{~kW}_{\mathrm{e}}-2 \mathrm{MW} \\
\text { e(A) } \\
\text { - PEMFC: } 1 \mathrm{~kW}_{\mathrm{e}}-250 \mathrm{~kW} \\
\text { - } \text { (A) } \\
\text { - SOFC: } 1 \mathrm{~kW}_{\mathrm{e}}-5 \mathrm{MW}_{\mathrm{e}} \text { (A) }\end{array}$ & $\begin{array}{l}\text { - } 35 \%-60 \% \text { (IEA) } \\
\text { - MCFC: } \pm 50-55 \% \text { (IEA) } \\
\text { - PAFC: } \pm 35 \% \text { (IEA) } \\
\text { - PEMFC: } \pm 35 \% \text { (IEA) } \\
\text { P SOFC: } \pm 50-55 \% \text { (IEA) } \\
\text { - Electric efficiency of } \\
\text { small-scale applications } \\
: \sim 25 \%\end{array}$ & $\begin{array}{l}\text { - PEMFC: low } \\
\text { temperature } \\
\text { applications in transport } \\
\text { and stationary use } \\
\text { - MCFC: high } \\
\text { temperature } \\
\text { - Transport sector is } \\
\text { major potential market } \\
\text { - SOFC: high } \\
\text { temperatures } \\
\text { - Power generation is the } \\
\text { most likely immediate } \\
\text { application } \\
\text { - CHP, UPS }\end{array}$ & $\begin{array}{ll}- & \text { Methanol } \\
\text { Hydrogen or natural } \\
\text { gas. Reforming of } \\
\mathrm{CH}_{4} \text { to } \mathrm{H}_{2} \text { leads to } \\
\text { decreased efficiency }\end{array}$ & \\
\hline Photovoltaic & - Generates no heat & $\begin{array}{l}-1+\mathrm{kW}(\mathrm{IEA}) \\
\text { - } 20+\mathrm{kW}(\mathrm{A}) ; \\
\text { - Every range possible } \\
\text { when using more cells }\end{array}$ & - not applicable & $\begin{array}{l}\text { - Household and small } \\
\text { commercial applications } \\
\text { - Off-grid applications } \\
\text { - Developing countries } \\
\text { - Small scale applications }\end{array}$ & - Sun & $\begin{array}{l}\text { - Non predictable output; } \\
\text { capacity factor 10- } \\
15 \% \text { in Western Europe }\end{array}$ \\
\hline Wind & - on shore and in-land & - $200 \mathrm{~W}-3 \mathrm{MW}(\mathrm{A})$ & - not applicable & & - Wind & $\begin{array}{l}\text { - Non predictable output } \\
\text { - Capacity factor on } \\
\text { shore } \sim 20-25 \%\end{array}$ \\
\hline Other Renewables & $\begin{array}{l}\text { - Includes thermal solar, } \\
\text { small hydro, } \\
\text { geothermal, ocean... }\end{array}$ & & - not applicable & & & \\
\hline
\end{tabular}

Table constructed on the basis of information found in Ackermann et al. (2001) (A) and IEA (2002). Emissions include direct and indirect emissions.

Table 1: Distributed generation technologies and characteristics. 


\section{WHY USE DISTRIBUTED GENERATION?}

In the introduction, it was mentioned that the IEA identifies 5 major factors that contribute to the renewed interest in distributed generation. We feel that these five factors can be further reduced to two major driving forces, i.e. electricity market liberalisation and environmental concerns. This section discusses these major driving forces. The developments in small-scale generation technologies have been around for a long time, but were as such not capable of pushing the "economy of scale" out of the system. We doubt that distributed generation is capable of postponing, and certainly not of avoiding, the development of new transmission lines, as, at the minimum, the grid has to be available as backup supply.

\section{The liberalisation of electricity markets}

There is the increased interest by electricity suppliers in distributed generation because they see it as a tool that can help them to fill in niches in a liberalised market. In such a market, customers will look for the electricity service best suited for them. Different customers attach different weights to features of electricity supply, and distributed generation technologies can help electricity suppliers to supply the type of electricity service they prefer. In short, distributed generation allows players in the electricity sector to respond in a flexible way to changing market conditions. Some major examples are discussed below.

In liberalised markets, it is important to adapt to the changing economic environment in the most flexible way. Distributed generation technologies in many cases provide this flexibility because of their small sizes and the short construction lead times compared to most types of larger central power plants. According to the IEA (2002), the value of their flexibility is probably understated when economic assessments of distributed generation are made ${ }^{\mathrm{iii}}$. However, it should be stated that the lead time reduction is not always that evident. For example, public resistance to for instance wind energy and use of landfill gasses may be very high.

\section{Standby capacity or peak use capacity (peak shaving)}

Many distributed generation technologies are indeed flexible in several respects: operation, size and expandability. For example, making use of distributed generation allows a flexible reaction to electricity price evolutions. Distributed generation then serves as a hedge against these price fluctuations. Apparently, this is the major driver for the US demand for distributed generation, i.e. using distributed generation for continuous use or for peaking use (peak shaving). In Europe, market demand for distributed generation is, for the moment, driven by heat applications, the introduction of renewables and by potential efficiency improvements. These will be discussed below.

\section{Reliability and Power Quality}

The second major driver of US demand for distributed generation is quality of supply or reliability considerations. Reliability problems refer to sustained interruptions, which are voltage drops to near zero (usually called outages), in electricity supply. The liberalisation of energy markets makes customers more aware of the value of reliable electricity supply. In many European countries, the reliability level has been very high, mainly because of high engineering standards. Customers do not really care about supply interruptions because they do not feel it 
as a great risk. This can change in liberalised markets, because a high reliability level implies high investment and maintenance costs for the network and generation infrastructure. Because of the incentives for cost-effectiveness that come from the introduction of competition in generation and from the re-regulation of the network companies, it might be that reliability levels will decrease. However, having a reliable power supply is very important for industry (chemicals, petroleum, refining, paper, metal, telecommunications...). Firms in these industries may find the reliability of the grid supplied electricity too low and they will decide to invest in distributed generation units in order to increase their overall reliability of supply to the desired level.

The IEA (2002) recognises the provision of reliable power as the most important future market niche for distributed generation. It identifies two distributed generation technologies that could provide protection against power interruptions, i.e. fuel cells and backup systems combined with a UPS system (uninterruptible power supply) ${ }^{\mathrm{iv}}$. Also gas- and diesel engines combined with a fly-wheel to cover the start-up time are being commercialised. The reliability issue is rather new in Europe, contrary to the US, where a significant amount of research has been done on this issue.

Apart from large voltage drops to near zero (reliability problems), one can also have smaller voltage deviations. The latter deviations are aspects of power quality. Power quality refers to the degree to which power characteristics align with the ideal sinusoidal voltage and current waveform, with current and voltage in balancev. Thus, strictly speaking, power quality encompasses reliability.

Insufficient power quality can be caused by (1) failures and switching operations in the network, which mainly result in voltage dips, interruptions, and transients ${ }^{\mathrm{vi}}$; and (2) by network disturbances from loads that mainly result in flicker (fast voltage variations), harmonics, and phase imbalance. The nature of these disturbances is related to the 'short-circuit capacity', being a measure for the internal impedance, in the network, which depends on the network's internal configuration (e.g., length of the lines, short-circuit capacity of generators and transformers, etc.). To protect the system from degradation in power quality, it is important for network operators to guarantee a specified minimum short-circuit capacity (Renner and Fickert (1999)).

The relation between distributed generation and power quality is an ambiguous one. On the one hand, many authors stress the healing effects of distributed generation for power quality problems. For example, in areas where voltage support is difficult, distributed generation can contribute because connecting distributed generation generally leads to a rise in voltage in the network (IEA (2002)). Dondi et al. (2002) also mention the potential positive effects of distributed generation for voltage support and power factor corrections.

On the other hand, the large-scale introduction of decentralised power generating units may lead to instability of the voltage profile: due to the bi-directional power flows and the complicated reactive power flows arising when insufficient control is introduced, the voltage throughout the grid may fluctuate. Additionally, bi-directional power flows make it difficult to tune the protection systems in the grid: short-circuits and overloads are supplied by multiple sources, each independently not detecting the anomaly. Eventually an 'islanding' situation may occur in which a local generator keeps a part of a disconnected grid energized leading to dangerous situation for the repair personnel coming. 
Others also stress the potential negative externalities on power quality, caused by the installation of distributed generation capacity. We will return to this in section 3 .

\section{Alternative to expansion or use of the local network}

Distributed generation could serve as a substitute for investments in transmission and distribution capacity (demand for distributed generation from T\&D companies) or as a bypass for transmission and distribution costs (demand for distributed generation from electricity customers). Of course, this is possible only to the extent that alternative primary fuels are locally available in sufficient quantities. For example, increased use of distributed generation could result in new congestion problems in other networks, such as the gas transport network.

According to the IEA (2002), on-site production could result in cost savings in transmission and distribution of about $30 \%$ of electricity costs. As such, it is seen as one of the biggest potential drivers for the distributed generation demand. In general, the smaller the customer size, the larger the share of transmission and distribution costs in the electricity price (above $40 \%$ for households).

From the point of view of the system operators, distributed generation units can substitute for investments in transmission and distribution capacity. In some cases, and with a different control, a distributed generation unit can even be used as an alternative to connecting a customer to the grid in a 'stand alone' application. Furthermore, well chosen distributed generation locations (i.e. close to the load) can also contribute to reduced grid losses. The IEA (2002) reports average grid losses of $6,8 \%$ in the OECD countries and according to Dondi et al. (2002), cost savings of $10 \%$ to $15 \%$ can be achieved in this way. However, a group of Belgian energy experts conclude that these results are correct only when the distributed generation units are stand-alone units and don't appeal to the grid (AMPERE (2000)). If not they are jointly responsible for the distribution grid and its losses.

\section{Grid support}

Finally, distributed generation can also contribute in the provision of ancillary services. These include services necessary to maintain a sustained and stable operation of the grid, but not directly supplying customers. This may be the capability to generate on demand of the grid operator, for instance to stabilize a dropping frequency due to a sudden undercapacity (e.g. a power plant switching off due to technical problems) or excess demand.

\section{Environmental concerns}

At present, environmental policies or concerns are probably the major driving force for the demand for distributed generation in Europe. Environmental regulations force players in the electricity market to look for cleaner energy- and cost-efficient solutions. Here, distributed generation can also play a role, as it allows optimising the energy consumption of firms that have a large demand for both heat and electricity (see Table 1 for the list of technologies that allow for CHP applications). Furthermore, most government policies that aim to promote the use of renewables will also result in an increased impact of distributed generation technologies, as renewables, except for large hydro, have a decentralised nature. 


\section{Combined generation of heat and electricity}

Especially on sites where there is a considerable and relatively constant demand for heat, it makes sense to consider the combined generation of heat and electricity instead of generating the heat in a separate boiler and buying electricity from the grid. These so-called cogeneration units form a large segment of the distributed generation market. Compared to separate fossilfired generation of heat and electricity, CHP generation may result in a primary energy conservation, varying from $10 \%$ to $30 \%$, depending on the size (and efficiency) of the cogeneration units. The avoided emissions are in a first approximation similar to the amount of energy saving, although the interaction with the global electricity generation system also plays a role ${ }^{\text {vii. }}$.

\section{Efficient use of cheap fuel opportunities}

Installing distributed generation allows the exploitation of cheap fuel opportunities. For example, in the proximity of landfills, distributed generation units could burn landfill gasses. But other locally available biomass resources may also be envisaged.

In short, the liberalisation of the electricity market and increased environmental concerns both induce an increased interest in distributed generation applications and thus also in innovations in the appropriate technologies. However, the economic as well as technical challenge will be to optimally integrate this increasing number of small generation units in an electricity system that up to now has been very centralised, integrated and planned.

Table 2 lists the different distributed generation technologies and indicates their potential benefits. 


\begin{tabular}{|c|c|c|c|c|c|c|c|c|c|}
\hline & Standby & Peak Shaving & Reliability & Power Quality & $\begin{array}{l}\text { Avoiding Grid } \\
\text { expansion }\end{array}$ & $\begin{array}{c}\text { Grid support } \\
\text { (Ancillary } \\
\text { services) }\end{array}$ & Co-generation & Green power & $\begin{array}{c}\text { Cheap fuel } \\
\text { opportunities }\end{array}$ \\
\hline $\begin{array}{l}\text { Reciprocating } \\
\text { Engines }\end{array}$ & Yes & Yes & $\begin{array}{c}\text { Yes, if } \\
\text { dispatchable }\end{array}$ & & $\begin{array}{c}\text { Yes, if } \\
\text { dispatchable }\end{array}$ & $\begin{array}{c}\text { Yes, if } \\
\text { dispatchable }\end{array}$ & Yes & $\mathrm{No}-\mathrm{Yes}^{(1)}$ & $\mathrm{No}-\mathrm{Yes}^{(1)}$ \\
\hline Gas turbines & Yes & Yes & $\begin{array}{c}\text { Yes, if } \\
\text { dispatchable }\end{array}$ & & $\begin{array}{c}\text { Yes, if } \\
\text { dispatchable }\end{array}$ & $\begin{array}{c}\text { Yes, if } \\
\text { dispatchable }\end{array}$ & Yes & No $-Y_{e s}^{(1)}$ & No $-Y_{e s}^{(1)}$ \\
\hline Micro turbines & Yes & Yes & $\begin{array}{c}\text { Yes, if } \\
\text { dispatchable }\end{array}$ & & $\begin{array}{c}\text { Yes, if } \\
\text { dispatchable }\end{array}$ & $\begin{array}{c}\text { Yes, if } \\
\text { dispatchable }\end{array}$ & Yes & No $-Y_{e s}^{(1)}$ & No $-Y_{e s}^{(1)}$ \\
\hline Fuel cells & Yes & No & $\begin{array}{c}\text { Yes, if } \\
\text { dispatchable }\end{array}$ & & $\begin{array}{c}\text { Yes, if } \\
\text { dispatchable }\end{array}$ & $\begin{array}{c}\text { Yes, if } \\
\text { dispatchable }\end{array}$ & Yes & $\mathrm{No}-\mathrm{Yes}^{(2)}$ & No \\
\hline Photovoltaic & No & No & No & No & Difficult & Difficult & No & Yes & Yes \\
\hline Wind & No & No & No & No & Difficult & Difficult & No & Yes & Yes \\
\hline Other Renewables & No & No & No, except hydro & & Difficult & Difficult & $\begin{array}{c}\text { No, except } \\
\text { biomass as fuel }\end{array}$ & Yes & Yes \\
\hline
\end{tabular}

Yes: $\quad$ technology contributes to ...;

No: $\quad$ technology does not contribute to....

(1): Green power is possible when bio-gas or bio-diesel is used

$\begin{array}{ll}\text { (1): } & \text { Green power is possible when bio-gas or bio-diesel is used } \\ \text { (2): } & \text { Green power is possible when hydrogen is produced via electrolysis, using wind- or solar energy }\end{array}$

Table 2: Distributed generation technologies and their potential benefits. 


\section{WHAT ARE THE MAJOR POLICY ISSUES?}

The previous section surveyed the major potential benefits resulting from distributed generation investments. However, (too much) distributed generation could possibly also have some costs, both economic and environmental. This section discusses some of the major issues found in the literature. In the end, the size and the mix of the installed distributed generation capacity will depend on the relative size of the costs and benefits of each technology. The key remaining challenge is then to design a framework that fully reflects these costs and benefits to the economy and to the environment.

\section{High financial cost}

The IEA (2002) and many others claim that one of the major remaining issues is the relatively high capital costs per kW installed power compared to large central plants. Moreover, differences in capital costs between the different distributed generation technologies are also quite large, ranging from $€ 1000$ per $\mathrm{kW}$ to over $€ 20000$ per $\mathrm{kW}$ for combustion turbines and fuel cells, respectively. The capital costs of large central plants, on the contrary, vary from approximately $€ 750$ for gas-fired plants to $€ 1.300$ for IGCC's and $€ 1.600$ for nuclear plants (IEA (1998)).

The prices mentioned in Table 3 are current prices of the commercially available technologies on the existent market. It is clear that these prices are not stable yet and will change as a consequence of future technology and market developments.

\section{Less choice between more costly primary fuels?}

According to the IEA (2002), an increasing share of distributed generation in the installed generation capacity is likely to imply less choice between primary fuels. This could reduce the diversification of primary energy supplies. Given that most distributed generation technologies are (primarily) based on gas and that, in many cases, gas-based generation will replace coalbased generation (environmental pressure), the IEA (2002) expects an increased demand for and dependency on gas. The importance of this argument crucially depends on the market share of distributed generation in the total generation capacity, but also, for example, on the amount of cogeneration that is installed. Cogeneration will lead to increased fuel efficiencies and possibly a lower overall fuel use. The sign and size of the total effect is however difficult to estimate.

Another claim is that the primary fuel supply for distributed generation applications will usually be more costly than that for central generation. This is possibly related to economies of scale and market power in the demand for primary energy sources that can be used to obtain lower primary fuel prices.

\section{Economic Efficiency}

Economic efficiency refers to the principle that wasting valuable resources should be avoided. The extent to which distributed generation is integrated efficiently in the electricity market hinges upon the market structure, the market operation and upon pricing. 
In many countries, the structure of the electricity market is revised through the liberalisation process. The final market structure will have an influence on the penetration potential of distributed generation. An economically efficient deployment would require a liberalisation of the retail market in the sense that electricity customers then have the option to generate their own electricity in response to price if a dispatchable distributed generation technology is used (IEA (2002)). The technology should be dispatchable. Wind or CHP are therefore less suitable since they are mainly climate or heat-demand driven. If only wholesale market liberalisation is achieved, electricity customers would essentially be faced with a monopolist at the distribution level. This monopolist can easily discourage the installation of distributed generation, for example by charging high prices for ancillary services or by offering very low prices for distributed power supplied to the grid. Clearly, the regulator could play a role here, for example by fixing (minimum) buy-back prices, but these prices risk to be set at inefficient levels such that either too much or too little distributed generation capacity is installed.

Liberalisation at the retail level is not a sufficient condition for non-discriminatory access of distributed generation to the grid. Grid operators that own generation capacity also have an incentive to discriminate against distributed generation. A separation of generation and distribution transport activities is necessary to remove this incentive. In the latter case, some potential benefits mentioned in the previous section will be more difficult to realise (distributed generation as an alternative to grid expansion).

Often, the liberalisation of the electricity market has led to the introduction of spot markets for electricity. These markets play an important role in the balancing of supply and demand. Generators and retailers unable to meet their forecasted output or demand must turn to the balancing market where they pay high prices for their imbalances. Clearly, distributed generators are adversely affected by this evolution because they typically have difficulties to forecast their output (heat driven or renewable).

In principle, prices should reflect underlying demand and supply conditions, which can vary over time and place. In practice, electricity prices are rarely sensitive to location, except when there are important technical reasons for price differences found in the grid, and in many cases they are also not sensitive to time, except for corrections for day/night or weekend and seasonal. Pricing mechanisms based on varying demand and supply conditions will encourage an efficient use and deployment of (distributed) generation. The use of time based pricing schemes is increasing (peak-load pricing, time-of-use rates...), but location based pricing schemes are apparently more difficult to implement.

\section{Environmental protection}

From the point of view of fuel utilization, smaller distributed generation plants generally are less efficient than larger central plants of the same type. Only when operating in a "combined heat and power" mode, they may conserve primary energy compared to the separate generation of electricity and heat in BAT-electric-power plants and high-efficiency boilers. The environmental burden per unit of output (electricity or heat) is not easy to pinpoint in that the allocation of the emissions to the electricity or heat side is not straightforward. This allocation may be done energetically or exergetically, and based on direct or avoided emissions. Although there are good thermodynamic reasons to argue that the allocation most justified is that based on the exergetic philosophy of avoided emissions, it is recommended to avoid the (actually 
undetermined) allocation and to compare CHP with separate generation. The primary power saving of CHP compared to separate generation reads

$$
P P S=\left(\frac{\alpha_{E}}{\eta_{E}}+\frac{\alpha_{Q}}{\eta_{Q}}-1\right) \cdot \dot{F}
$$

in which $\alpha_{E}$ and $\alpha_{Q}$ are the electric and thermal efficiencies of the CHP, respectively, $\eta_{E}$ and $\eta_{Q}$ are electric and thermal efficiencies of the electric power plant and the boiler in the case of separate generation and $\dot{F}$ is the fuel input power in the CHP. With $\mathrm{Cl}$ the emission coefficient of the primary driver (gas turbine, engine, etc.) of the CHP per unit primary input, i.e.,

$$
\mathrm{Cl}=\frac{\text { amount emitted in }(\mathrm{kg} / \mathrm{s})}{\text { primary fuel input in }(\mathrm{J} / \mathrm{s})}
$$

the avoided emission of the CHP per unit of primary fuel input in the CHP compared to separate generation reads

$$
\text { Avoided emissions }=\left(\frac{\alpha_{E}}{\eta_{E}}+\frac{\alpha_{Q}}{\eta_{Q}}-1\right) . C l
$$

This illustrates that the increased use of distributed generation is not always beneficial for the environment. It certainly would be the case for some technologies and applications, but it cannot be generalised. The outcome will crucially depend on the market share of the different distributed generation technologies and on the mix of central generation that is replaced.

As far as renewable distributed-generation units are concerned, only indirect emissions have to be taken into account. Since this paper does not intend to make life-cycle assessments for the different technologies, the reader is referred to Voorspools et al. (2000) to get a quantitative idea of these indirect emissions.

\section{Energy Security}

In some discussions, energy security is linked to the diversification of primary energy supplies, in others, it is interpreted as the reliability of the electricity system. Under the first interpretation, energy security improves as the diversification of primary energy supplies increases. In this case, the advantages of distributed generation are limited, as most technologies - with the exception of systems based on renewables -directly or indirectly depend on natural gas.

Under the second interpretation, it is felt by many authors, for example by the IEA (2002), that distributed generation can contribute to reduce the risks and costs of blackouts. Here, distributed generation is seen as an instrument that helps to reduce the private costs and risks for electricity customers of system failures. Others, like CIRED (1999), claim that distributed generation does not contribute to system security viii. On the contrary, it would have a negative effect. Such a negative impact on the system security occurs when the share of nondispatchable generation capacity increases. Examples of such units are wind turbines, photovoltaic systems and cogeneration units that are closely tied to heat demand. The latter units cannot be centrally controlled because of the natural variability of their power supply. As a consequence, there is an increased need for regulating (backup) power. 


\section{Power Quality}

From the CIRED (1999) questionnaire, we know that some European countries raise power quality as an issue in the current electricity market evolutions. Depending on the aspect chosen, distributed generation can either contribute to or deteriorate power quality. Here, we focus on some potential problems.

\section{System Frequency}

Imbalances between demand and supply of electricity cause the system frequency to deviate from the rated value of $50 \mathrm{~Hz}$. These deviations should be kept within very narrow margins, as the well functioning of many industrial and household applications depends on it. In economic terms, system frequency can be considered as a public good. As a consequence, the transmission grid operator is appointed to take care of the system frequency as well as of other services with a public good character that need to be provided.

The installation and connection of distributed generation units is also likely to affect the system frequency. These units will free ride on the efforts of the transmission grid operator or the regulatory body to maintain system frequency. The latter will probably have to increase their efforts and this could have an impact on the efficiency of plants and on their emissions. Therefore, the connection of an increasing number of distributed generation units should be carefully evaluated and planned upfront.

\section{Voltage level}

According to Ackermann et al. (2001), the impact on the local voltage level of distributed generation connected to the distribution grid can be significant. A same reaction was noted through the CIRED (1999) questionnaire, where, next to the general impact on power quality, a rise in the voltage level in radial distribution systems was mentioned as one of the main technical connection issues of distributed generation. The IEA (2002) also mentions voltage control as an issue when distributed generation is connected to the distribution grid. This does not need to be a problem when the grid operator faces difficulties with low voltages, as in that case the distributed generation unit can contribute to the voltage support. But in other situations it can result in additional problems.

\section{Connection issues}

\section{Change in power flow}

Power can flow bidirectional within a certain voltage level, but it usually flows unidirectional from higher to lower voltage levels, i.e. from the transmission to the distribution grid. An increased share of distributed generation units may induce power flows from the low-voltage into the medium-voltage grid. Thus, different protection schemes at both voltage levels may be required (Dondi et al. (2002)).

\section{Protection}

Distributed generation flows can reduce the effectiveness of protection equipment. Customers wanting to operate in 'islanding' mode during an outage must take into account important technical (for instance the capability to provide their own ancillary services) and safety 
considerations, such that no power is supplied to the grid during the time of the outage. Once the distribution grid is back into operation, the distributed generation unit must be resynchronised with the grid voltage.

\section{Reactive power}

Small and medium sized distributed generation units mostly use asynchronous generators that are not capable of providing reactive power. Several options are available to solve this problem. On the other hand, DG units with a power electronic interface are sometimes capable to deliver a certain amount of reactive power.

\section{Power Conditioning}

Some distributed generation technologies (PV, fuel cells) produce direct current. Thus, these units must be connected to the grid via a DC-AC interface, which may contribute to higher harmonics. Special technologies are also required for systems producing a variable frequency AC voltage. Such power electronic interfaces have the disadvantage that they have virtually no 'inertia', which can be regarded as a small energy buffer capable to match fast changes in the power balance. Similar problems arise with variable wind speed machines.

A: Ackerman et al. (2001).

Table 3 lists an overview of the different distributed generation technologies and their economic and environmental issues. 


\begin{tabular}{|c|c|c|c|c|c|c|c|}
\hline & $\begin{array}{l}\text { Investment cost } \\
\text { per } k W_{e}\end{array}$ & $\begin{array}{l}\text { Increased market } \\
\text { share of gas }\end{array}$ & $\begin{array}{l}\text { Opportunities to } \\
\text { contribute to higher } \\
\text { economic efficiency } \\
\text { in liberalised } \\
\text { markets }\end{array}$ & $\begin{array}{c}\mathrm{CO}_{2} \text { Emissions } \\
(\mathrm{g} / \mathrm{kWh}) \text { in non-CHP } \\
\text { mode }\end{array}$ & $\begin{array}{c}N O_{x} \text { Emissions } \\
(\mathbf{g} / \mathbf{k W h})\end{array}$ & $\begin{array}{l}\mathrm{SO}_{2} \text { Emissions } \\
(\mathbf{g} / \mathbf{k W h})\end{array}$ & Dispatchable \\
\hline $\begin{array}{l}\text { Reciprocating } \\
\text { Engines }\end{array}$ & $€ 1500-2500$ & Yes & $\begin{array}{l}\text { Yes, but depends on } \\
\text { thermodynamic } \\
\text { efficiency }\end{array}$ & $\begin{array}{l}\text { Diesel: CO2: } 650 \\
\text { (IEA) } \\
\text { Gas: } 500 \text { - } 620 \text { (IEA) }\end{array}$ & $\begin{array}{l}\text { Diesel: } 10 \text { (IEA) } \\
\text { Gas: } 0,2 \text { - } 1 \text { (IEA) }\end{array}$ & & Possible, but unlikely \\
\hline Gas turbines & $€ 1000-1250$ & Yes & Yes & $580-680$ (IEA) & $0,3-0,5$ (IEA) & & Possible, but unlikely \\
\hline Micro turbines & $€ 1500-2000$ & Yes & $\begin{array}{l}\text { Depends on } \\
\text { thermodynamic } \\
\text { efficiency }\end{array}$ & 720 (IEA) & 0,1 (IEA) & & Possible, but unlikely \\
\hline Fuel cells & $\begin{array}{l}€ 4500-20000 \\
\text { (IEA) or more }\end{array}$ & Possible & $\begin{array}{l}\text { Yes, but depends on } \\
\text { thermodynamic } \\
\text { efficiency }\end{array}$ & $\begin{array}{l}\text { Depends largely on } \\
\text { the fuel used, power } \\
\text { output and efficiency }\end{array}$ & $0,005-0,01$ (IEA) & & Possible, but unlikely \\
\hline Photovoltaic & $€ 5000-7000$ (IEA) & No & No & $\begin{array}{l}0 \text { (IEA); } \\
200-250(A) ; \\
\text { Indirect emissions }\end{array}$ & $\begin{array}{l}0 \text { (IEA) } \\
0,160-0,340(\mathrm{~A}) \\
\text { Indirect emissions }\end{array}$ & $\begin{array}{l}0,135-0,330(\mathrm{~A}) \\
\text { Indirect emissions }\end{array}$ & No \\
\hline Wind & $\begin{array}{l}€ 800-1000 \text { on } \\
\text { shore } \\
€ 2000 \text { off shore }\end{array}$ & No & No & $\begin{array}{l}4,5 \mathrm{~m} / \mathrm{s}: 19-34(\mathrm{~A}) \\
\text { 5,5m/s: } 13-22(\mathrm{~A}) \\
6,5 \mathrm{~m} / \mathrm{s}: 10-17(\mathrm{~A}) \\
\text { Indirect emissions }\end{array}$ & $\begin{array}{l}4,5 \mathrm{~m} / \mathrm{s}: 0,026-0,043 \\
\text { (A) } \\
5,5 \mathrm{~m} / \mathrm{s}: 0,018-0,027 \\
\text { (A) } \\
6,5 \mathrm{~m} / \mathrm{s}: 0,014-0,022 \\
\text { (A) } \\
\text { Indirect emissions }\end{array}$ & $\begin{array}{l}4,5 \mathrm{~m} / \mathrm{s}: 0,018-0,032 \\
\text { (A) } \\
5,5 \mathrm{~m} / \mathrm{s}: 0,013-0,020 \\
\text { (A) } \\
6,5 \mathrm{~m} / \mathrm{s}: 0,010-0,016 \\
\text { (A) } \\
\text { Indirect emissions }\end{array}$ & No \\
\hline Other Renewables & & No & No & & & & \\
\hline
\end{tabular}

Table 3: Distributed generation technologies and the issues. 


\section{DEFINITION OF DISTRIBUTED GENERATION}

In the previous sections, distributed generation was loosely defined as small-scale electricity generation. But what exactly is small-scale electricity generation? The different technologies that can be used for it were listed in Table 1, but is it possible to give a more concrete definition? A short survey of the literature shows that there is no consensus. This is confirmed by CIRED (1999), on the basis of a questionnaire submitted to the member countries. Some countries define distributed generation on the basis of the voltage level, whereas others start from the principle that distributed generation is connected to circuits from which consumer loads are supplied directly. Other countries define distributed generation as having some basic characteristic (for example, using renewables, cogeneration, being non-dispatched...).

CIGRE $^{\text {ix }}$ also has a working group that devotes efforts to distributed generation. This working group defines distributed generation as all generation units with a maximum capacity of $50 \mathrm{MW}$ to $100 \mathrm{MW}$, that are usually connected to the distribution network and that are neither centrally planned nor dispatched ${ }^{\mathrm{x}}$. Clearly, this latter part of their definition implies that distributed generation units are beyond the control of the transmission grid operator. Thus, generation units built by the transmission grid operator as a substitute for grid expansion and that have measures implemented for dispatching are not considered to be distributed generation according to this philosophy.

The IEEE defines distributed generation as the generation of electricity by facilities that are sufficiently smaller than central generating plants so as to allow interconnection at nearly any point in a power system ${ }^{\mathrm{xi}}$.

On the basis of the definitions surveyed in their paper, Dondi et al. (2002) define distributed generation as a small source of electric power generation or storage (typically ranging from less than a kW to tens of MW) that is not a part of a large central power system and is located close to the load. These authors also include storage facilities in the definition of distributed generation, which is not conventional. Furthermore, their definition emphasises the relatively small scale of the generation units as opposed to CIRED and CIGRE.

Chambers (2001) also defines distributed generation as relatively small generation units of $30 \mathrm{MW}$ or less. These units are sited at or near customer sites to meet specific customer needs, to support economic operation of the distribution grid, or both.

With the exception of the CIGRE definition, all definitions assume that distributed generation units are connected to the distribution network. This is also the case for the definition used by IEA (2002), which sees distributed generation as units producing power on a customer's site or within local distribution utilities, and supplying power directly to the local distribution network. IEA, however, makes no reference to the generation capacity level as opposed to all other definitions.

It should be clear by now, that many definitions of distributed generation exist, allowing for a wide range of possible generation schemes. Some definitions allow for the inclusion of largerscale cogeneration units or large wind farms connected to the transmission grid, others put the focus on small-scale generation units connected to the distribution grid. All these definitions suggest that at least the small-scale generation units connected to the distribution grid are to be considered as part of distributed generation. Moreover, generation units installed close to the 
load or at the customer side of the meter are also commonly identified as distributed generation. This latter criterion partially overlaps with the first, as most of the generation units on customer sites are also connected to the distribution grid. However, it also includes somewhat larger generation units, installed on customer sites, but connected to the transmission grid.

This leads to the definition proposed by Ackermann et al. (2001), who define distributed generation in terms of connection and location rather than in terms of generation capacity. They define a distributed generation source as an electric power generation source connected directly to the distribution network or on the customer side of the meter. We favour this definition, even though it is rather broad. Indeed, it puts no limit on the technology or capacity of the potential distributed generation application. Therefore, some additional criteria can be helpful and necessary to further narrow the definition in function of the research question that is tackled. The following paragraphs list a (non-exhaustive) number of these criteria along with a short discussion ${ }^{\text {xii }}$.

\section{Voltage level at grid connection (transmission/distribution)}

Although some authors allow distributed generation to be connected to the transmission grid, most authors see distributed generation as being connected to the distribution network, either on the distribution or on the consumers' side of the meter. In all cases, the idea is accepted that distributed generation should be located closely to the load. The problem is that a distinction between distribution and transmission grid, based on voltage levels, is not always useful, because of the existing overlap of these voltage levels for lines in the transmission and distribution grid. Moreover, the 'legal' voltage level that distinguishes distribution from transmission can differ from region to region. Therefore, it is best not to use the voltage level as an element of the definition of distributed generation. It would be more appropriate to use the concepts 'distribution network' (usually radial) and 'transmission network' (usually meshed) and to refer to the legal definition of these networks as they are used in the country under consideration.

\section{Generation capacity (MW)}

One of the most obvious criteria would be the generation capacity of the units installed. However, the short survey of definitions illustrated that there is no agreement on maximum generation capacity levels and the conclusion is that generation capacity is not a relevant criterion. The major argument is that the maximum distributed generation capacity that can be connected to the distribution grid is a function of the capacity of the distribution grid itself. Because this latter capacity can differ widely, it is not possible to include it as an element of the definition of distributed generation. However, this does not imply that the capacity of the connected generation units is not important. On the contrary, many of the policy issues and benefits discussed in the sections 2 and 3 are related to the capacity of the generation units. Thus, a narrowed definition of distributed generation could, among other things, be based on the generation capacity criterion.

\section{Services supplied}

Generation units should by definition at least supply active power in order to be considered as distributed generation. The supply of reactive power and/or other ancillary services is possible and may represent an added value, but is not necessary. 


\section{Generation technology}

In some cases, it can be helpful to clarify the general definition of distributed generation by summing up the generation technologies that are taken into account. It would however be difficult to use this approach to come to a definition because the availability of (scalable) technologies and of capacities, especially in the field of renewables, differs between countries. Also conventional systems such as gas turbines are available over wide ranges (a few $\mathrm{kW}$ to $500 \mathrm{MW})$.

Sometimes, it is claimed that distributed generation technologies should be renewable. However, it should be clear from section 1 that many small-scale generation technologies exist that do not use renewables as a primary source. On the other hand, not all plants using 'green' technologies are supplying distributed generation. This would, for example, depend on the plant size or on the grid to which the installation is connected (transmission or distribution). Should a large offshore wind farm of $100 \mathrm{MW}$ be considered as distributed generation? And what about a large hydro power plant located in the mountains?

\section{Operation mode}

Ackermann et al. (2001) do not consider the operation mode (being scheduled, subject to pool pricing, dispatchable...) as a key element in the general definition of distributed generation. This is a correct view, but at the same time it must be recognised that many of the problems related to distributed generation, essentially have to do with the fact that these generation units are beyond control of grid operators. So, it can be meaningful to use (elements of) the operation mode as a criterion to narrow the definition.

\section{Power delivery area}

In some cases, distributed generation is described as power that is generated and consumed within the same distribution network. As correctly stated by Ackermann et al. (2001), it would be difficult to use this as a criterion, even for a narrowed definition, because it requires complex power flow analyses.

\section{Ownership}

Ackermann et al. (2001) do not consider ownership as a relevant element for the definition of distributed generation. Thus, customers, IPPs and traditional generators can own distributed generation units.

\section{SUMMARY AND CONCLUSIONS}

This paper started from the observed renewed interest in small-scale electricity generation. Existing small-scale generation technologies are described and the major benefits and issues of using small-scale distributed generation are discussed. The different technologies are evaluated in terms of their contribution to the listed benefits and issues.

Small-scale generation is commonly called distributed generation and we try to derive a consensus definition for this latter concept. It appears that there is no agreement on a precise definition as the concept encompasses many technologies and many applications in different environments. In our view, the best definition of distributed generation that generally applies 
seems to be 'an electric power generation source that is connected directly to the distribution network or on the customer side of the meter'. Depending on the interest or background of the one confronted with this technology, additional limiting aspects might be considered, such as being dispatchable or not. A further narrowing of this 'common divider' definition might be necessary depending on the research questions that are looked at. However, the general and broadly understandable description as proposed here, is required to allow communicating on this concept. 


\section{REFERENCES}

ACKERMANN, T., ANDERSSON, G., SÖDER, L., 2001. Distributed generation: a definition, Electric Power Systems Research, vol. 57, p. 195-204.

AMPERE, 2000. http://mineco.fgov.be/energy/ampere_commission/Rapport_nl.htm.

CHAMBERS, A., 2001. Distributed Generation: A Nontechnical Guide, PennWell, Tulsa, Oklahoma, p. 283.

CIRED, 1999. Dispersed generation, Preliminary report of CIRED working group WG04, June, p. $9+$ Appendix (p.30).

DONDI, P., BAYOUMI, D., HAEDERLI, C., JULIAN, D., SUTER, M., 2002. Network integration of distributed power generation, Journal of Power Sources, vol. 106, p. 1-9.

ETO, J., KOOMEY, J., LEHMAN, B., en MARTIN, N., (2001), Scoping Study on Trends in the Economic Value of Electricity Reliability to the U.S. Economy, LBLN-47911, Berkeley, p. 134.

FEINSTEIN, C. D., MORRIS, P. A., CHAPEL, S. W., 1997. Capacity Planning Under Uncertainty: Developing Local Area Strategies for Integrating Distributed Resources, The Energy Journal, nr. DR special issue, p. 85-110.

FRAYER, J., ULUDERE, N., 2001. What is it worth? Applications of Real Options Theory to the Valuation of Generation Assets, The Electricity Journal, vol. 13, nr. 8, p. 40-51.

IEA, 1998. Projected costs of generating electricity in 2005 - 2010, update 1998.

IEA, 2002. Distributed Generation in Liberalised Electricity Markets, Paris, p. 128.

JENKINS, N., ALLAN, R., CROSSLEY, P., KIRSCHEN, D., and STRBAC, G., 2000. Embedded Generation, IEE, London, pp. 245.

OSBORN, J., KAWANN, C., 2001. Reliability of the U.S. Electricity System: Recent Trends and Current Issues, LBNL-47043, Berkeley, p. 44.

RENNER, H., FICKERT, L., 1999. Costs and responsibility of power quality in the deregulated electricity market, Graz. 
VOORSPOOLS, K., BROUWERS, E., D'HAESELEER, W., 2000. Energy content and indirect greenhouse gas emissions embedded in 'emission-free' power plants : results for the Low Countries, Applied Energy vol. 67, p. 307-330.

VOORSPOOLS, K., D'HAESELEER, W., 2002. The evaluation of small cogeneration for residential heating, International Journal of Energy Research, vol. 26, p. 1175-1190.

VOORSPOOLS, K., D'HAESELEER, W., 2003. The impact of the implementation of cogeneration in a given energetic context, IEEE Transactions on Energy Conversion, vol. 18 , p. $135-141$.

\footnotetext{
' All authors are affiliated to the K.U.Leuven Energy Institute. Comments by Bert Willems were appreciated. The authors take full responsibility for any remaining errors.

ii See for example Jenkins, Crossley et al (2000) for a more in depth discussion of the technical features of the different technologies.
}

iii Recent work based on option value theory suggests that flexible power plants operating during peak periods may be much more profitable than conventional evaluations suggest. See Feinstein, Morris et al. (1997) and Frayer and Uludere (2001) for some literature on this subject.

${ }^{\text {iv }}$ It has to be stressed however, that the fuel cell technology is currently not easily commercially available.

${ }^{\vee}$ Eto et al. (2001).

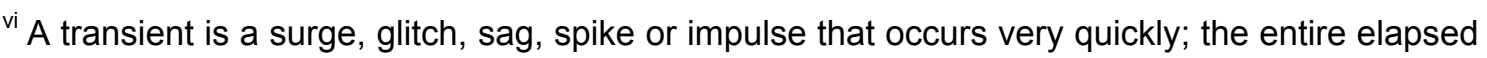
time can be less than two or three microseconds.

vii See for example Voorspools and D'haeseleer (2002) and Voorspools and D'haeseleer (2003).

viii CIRED is the International Conference of Electricity Distributors.

${ }^{\text {ix }}$ CIGRE is the International Council on Large Electricity Systems.

${ }^{\times}$CIRED (1999), p. 4.

${ }^{x i}$ IEEE stands for the Institute of Electrical and Electronics Engineers and the definition is taken from Dondi, Bayoumi et al. (2002), p. 2. 
${ }^{x i i}$ This discussion is largely based on Ackermann et al. (2001). 